\title{
FEMINISM REALITY AS EXPRESSED BY SUMARNI IN THE YEARS OF THE VOICELESS NOVEL BY OKKY MADASARI: A CRITICAL DISCOURSE ANALYSIS
}

\author{
Ayu Monita Eka Shinta
}

31220101185@mhs.dinus.ac.id

Universitas Dian Nuswantoro

\begin{abstract}
This thesis entitled Feminism Reality as Expressed by Sumarni in the Years of the Voiceless Novel by Okky Madasari: A Critical Discourse Analysis is conducted to convey position and feminism reality of woman as reflected by Sumarni in this novel. The subject of this study is the main character namely Sumarni regarded as a voiced civilian woman. The reason for choosing this novel is because of inequality power relation issues, especially woman. Women are considered as weak. Here, Sumarni appears as a main character who wants to speak up rather than to be voiceless. This study is intended to give a model in how woman can show her power through her utterances since woman wants to be equal in society. There were several steps in doing this study which have been done. Under the qualitative research, the data collection started from reading the novel and then selecting utterances. While the method of data analysis was done by grouping Sumarni's utterances, after that the utterances were analyzed by considering feminist stylistic elements at the level of sentence by using transitivity choices and Wodak's triangulatory approach. The result of this study reveals that the use of relational process is higher than material process intention and supervention, and mental process internalized and externalized. From the finding above, it can be seen that Sumarni appears as a not common woman since she can be a sugarcane field owner and moneylender in the end of the novel. In addition, there is a feminism reality as realized by Sumarni that a woman must be independent and be responsible both in society and family.
\end{abstract}

Keywords: CDA, feminist stylistics, feminism, The Years of the Voiceless, utterances

Women are commonly stereotyped as subordinate among men in society. The inequality places women in marginal position. Stereotype is also considered as an influence within women's position in society. The meaning of subordinate in the Cambridge Advanced Learner's Dictionary Third Edition (2008: 1452) is having a lower or less important position. Therefore, if women are still considered in this 
Ayu Monita Eka Shinta, Feminism Reality as Expressed by Sumarni in the Years of The Voiceless Novel by Okky Madasari: A Critical Discourse Analysis

position, it will lead to social problems when dominant groups exploit or oppress subordinate groups. On the other hand, this social problem makes women entirely dependent on the dominant one.

Women in every culture are mostly considered as subordinate class but in different perspective. Coates (1998: 143) even states the stereotype of women. It is noted that in Eastern culture, most of women are housewives, powerless, weak, obedient, soft, polite, feminine, shy, timid, emotional, and dependent. While in Western culture, women are receipted as sex objects, mother, childlike behavior, and iron maiden. Most of these parameters do exist in the society both at home and work places. It is not something new if a lot of women have few positions at work rather than men.

Based on the explanation above then there is a thought that although women are positioned as subordinate, they still have powers that cannot be seen explicitly. Women use implicit rather than explicit in explaining their ideas or showing their feelings. These ways sometimes are used as their power to control the society and circumstances. According to Cambridge Advanced Learner's Dictionary Third Edition (2008: 1109), power means the ability to control people and events. It also means an official or legal right to do something. Hence, power can also be understood as a system of shared meaning that reinforce mainstream ideas and silence alternatives. It has been shaped in society and cultures that people who have higher position are more powerful than labors or employees, so do women. It influences the way of them to use language among the lower ones.

The issue of woman's power is rising under the flag of women's emancipation. It has been noted in Wodak (1992: 474) that power has been the engine driving most research on language and gender. It is motivated partly by the desire to understand male dominance and partly by the desire to dismantle it which sometimes along with other social inequalities. This statement proves how this issue can be a motivation for women to be equal among men in society. The ways of women to show their power may have different perspective.

As a means of communication, people use language to socialize each other in society. Language can be understood more deeply in linguistics studies. Language also can determine which people are more powerful than others. It also shares knowledge in how powerless peoples can show their effort to get their rights. In stylistic, it has been explained that there are various models of language in the text analysis. From the point of feminist stylistic view, the models of language are seen as the most commonsense and simplistic view. It is also the form of social networking or social bonding, or as the site where power relations are negotiated and enforced. It can also be seen as a set of mutually exclusive choices in a closed system. These statements lead a lot of scholars in looking for women's model of language.

As a branch of linguistic study, critical discourse analysis is one of the studies which sees language at the level of discourse in social practice. Hence, it is very 
helpful to see how women's power influences other around them were interested to conduct in this study. Here, the researcher stood under the feminist flag since the data used Sumarni's utterances as the main character in the novel. Sumarni as the woman who lived under Indonesian Communist Party era in 1987 shows her struggle upon the pressures for her family. Indeed, government is more powerful because of the position labeling status. Then it becomes the reason of the novel's author places women, who were actually voiceless in that time, became brave to speak up. Nevertheless, as the belief of the researcher that as woman, Sumarni shows her power through utterances when answering ward chief, soldiers, neighbors or even her husband and daughter. It implies that women can show their power when there are injustices and inequality in the novel. This kind of power can be seen among every utterance of Sumarni when making conversation with the dominant ones.

The main idea of conducting this study was that for revealing feminism reality through her utterances. The data were taken from a novel entitled The Years of the Voiceless by Okky Madasari. Since the data used a novel as a literary text, there was a parameter of study. It can be seen from the decision of using Sumarni's utterances only rather than the all women's character because of the desire to focus on a feminist language model from the main character of a novel.

A feminist stylistic helps the researcher to understand literary texts which have a complex relation to both truth and value, on the one hand being seen as providing a 'truth' about the human condition. Moreover, it is yet doing so within a fictional and therefore 'untrue' form. This study tries to know the condition in particular time and in which position that a woman can be placed.

The utterances of Sumarni were analyzed by using linguistic perspectives. One of them is feminist critical discourse analysis. The aim of using feminist critical discourse analysis is advancing a rich of power in discourse in sustaining hierarchically gendered social orders. Below is the example of Sumarni's utterances:

\section{"But I want to, Kang. I need the money. I don't want to get paid with cassavas anymore."}

(Madasari, 2013: 30)

From the example above the author wants to show the condition of women in that time under Indonesia Communist Party era. She needs money and does not want to get paid by cassavas. According to the story that Sumarni's mother taught her for thankful that they can eat. By using CDA and feminist stylistic framework, this study shows the linguistic elements in revealing the women's utterances within the novel. As the suggestion from Wodak, the literary genre - such as fiction toward the emphasis of politics identity can be the new development of CDA.

There are lot of Indonesian scholars who have conducted this novel by using sociology, psychology, and literature theories. This study proposes a different view in analyzing woman's life based on feminism reality in a novel by critical discourse 
Ayu Monita Eka Shinta, Feminism Reality as Expressed by Sumarni in the Years of The Voiceless Novel by Okky Madasari: A Critical Discourse Analysis

analysis in linguistics perspective, especially by giving a new perspective that women have choices to get right in society.

\section{RESEARCH METHOD}

\section{Data and subject}

The data were taken from a novel entitled The Years of the Voiceless (2013) by Okky Madasari.

\section{Unit of Analysis}

In this research, the researcher discussed the analysis at the level of sentence which focused on certain clauses in selected utterances of Sumarni as the main character in The Years of the Voiceless.

\section{Technique of Data Collection and Analysis}

The data of this study were obtained by doing some steps. First, the researcher read the novel from beginning to the end. Thus the researcher selected 228 utterances of Sumarni as the main female character in the novel to be analyzed. After that, there were several steps in making analysis of the utterances. First, the researcher grouped every utterance of Sumarni as the main female character. Then, researcher analyzed utterances at the level of sentence by using transitivity choices. In displaying excerpts, the researcher coded the utterances as below:

Example:

\begin{tabular}{|l|l|}
\hline I usually carry baskets, even sacks. & material action intention [actor] \\
\hline
\end{tabular}

(Utterance 20, p. 30, 1. 512)

The bold utterance in the table above showed process in Sumarni's utterance. From the excerpt above, it can be read that the utterance was taken from number 20 of Sumarni's utterances in appendix 2. Then it can be found in line 512 on page 30 of the book. After the researcher analyzed the elements, the woman's position in the novel was analyzed using the triangulatory approach from Wodak in order to get the contextual meaning. After analyzing the data, the researcher made conclusions and suggestions.

\section{FINDING AND DISCUSSION}

\section{Finding}

Table 4.1 is the finding of the transitivity choices used by Sumarni as the main character in The Years of the Voiceless novel. 
Table 4.1 Transitivity Choices used by Sumarni in The Years of the Voiceless

\begin{tabular}{|c|c|c|c|c|c|}
\hline \multicolumn{6}{|c|}{ novel Transitivity Choices } \\
\hline \multicolumn{4}{|c|}{ Relational process } & 202 & $41.65 \%$ \\
\hline \multirow{5}{*}{$\begin{array}{l}\text { Material } \\
\text { process }\end{array}$} & \multirow{5}{*}{ Action } & \multirow{2}{*}{ Intention } & Actor & 142 & $29.28 \%$ \\
\hline & & & Affected & 24 & $4.95 \%$ \\
\hline & & \multirow{2}{*}{ supervention } & Actor & 19 & $3.92 \%$ \\
\hline & & & Affected & 9 & $1.86 \%$ \\
\hline & & \multicolumn{2}{|l|}{ Event } & 5 & $1.03 \%$ \\
\hline \multirow{2}{*}{$\begin{array}{l}\text { Mental } \\
\text { process }\end{array}$} & \multicolumn{3}{|c|}{ Internalized } & 68 & $14.02 \%$ \\
\hline & \multicolumn{3}{|c|}{ Externalized } & 16 & $3.29 \%$ \\
\hline \multicolumn{4}{|l|}{ Total } & 485 & $100.00 \%$ \\
\hline
\end{tabular}

The limitation on the feminist stylistic analysis at the level of sentence of utterances is focused on transitivity choices used by Sumarni in the novel. These elements are believed to convey power within Sumarni's utterances. From the table, it can be seen that transitivity choices which are mostly used are 202 relational processes, 142 material intention processes and 68 mental internalized processes in her utterances.

The table above reveals that Sumarni uses transitivity choices on her utterance. The result of relational processes can be seen from 202 utterances appears in hers. The use of material process intention [actor] is 142 utterances. The use of mental process internalized with 68 as the frequency numbers of utterances. While the material process intention as she is affected with the number of utterances 24 . The material process supervention [affected] appears 9 utterances and material process supervention [actor] appears 19 utterances. They are followed by mental process externalized (14 utterances). From 518 clause boundaries of the utterances, there are 485 or $93.63 \%$ of transitivity choices found as element to reveal power based on feminist stylistic.

\section{Discussion}

The discussions are divided into two sub-parts. The first is to convey the position of Sumarni since she plays an important role within it. The second is to know the feminism reality realized by Sumarni.

According to the findings that Sumarni mostly uses material process intention rather than supervention. High number of material process intention shows that Sumarni is a female character whom active in The Years of the Voiceless novel. However, there are two kinds of material process intention as an actor and an affected. As a female character, she gets suffered because of some situation. While the frequency number of intention actor appears 142 times higher than the 
Ayu Monita Eka Shinta, Feminism Reality as Expressed by Sumarni in the Years of The Voiceless Novel by Okky Madasari: A Critical Discourse Analysis

affected. This implies that although she gets suffered, she can raise up her inner spirit to control herself and other characters.

The material process supervention also has two distinctions, they are supervention actor and affected. If intention process is a process which is clearly will to do by someone consciously, the supervention is an attempt which is not done intentionally. Sumarni appears with supervention [affected] higher than [actor]. It shows that she does not out of control. The supervention [affected] is considered that she is not intentionally to do or say something. While the mental process internalized is higher than the externalized shows that Sumarni is a very introspective. She feels pity to her customers who come and lend some money.

In order to have a better view about the representation or the position of Sumarni, below are the excerpts of each.

\section{Relational processes}

It reveals that relational process is mostly used by Sumarni in her utterances. The use of relational process is helpful for Sumarni in explaining her status, idea, and situation. Below are the excerpts of relational processes in Sumarni's utterances.

\section{Excerpt 1}

\begin{tabular}{|l|l|}
\hline I need the money. & mental process internalized \\
\hline
\end{tabular}

(Utterance 20, p. 30, 1. 514-517)

The excerpt above shows that Sumarni needs money so that she wants to be a porter. It is used by Sumarni to strengthen her desire that she wants to earn money. At that time, a woman was paid by cassavas because there was a perception that having a lot of food to be able to eat is the most important. From the utterance above, Sumarni is not afraid to ask for a chance to have a man's job. The use of attributive intensive above implies that she is assigning her intention in front of Teja. She prefers to say explicitly about her need. This process intends to show that she does not have dignity to reveal it.

\section{Material Intention Processes [actor]}

This process indicates that Sumarni is an active woman character in the novel. The use of material process intention which Sumarni as an actor shows that she takes more active in doing something or affect other character. It can be seen when she delivers her utterances among other character. She mostly appears as an actor rather than an affected. In addition, one of the signs in how to see her as an active woman is from the activity she does which can be seen from her utterances. Below are the examples of her utterances containing material intention processes. 


\title{
Excerpt 12
}

\author{
\begin{tabular}{|l|l|}
\hline I usually carry baskets, even sacks. & Material intention process [actor] \\
\hline
\end{tabular} \\ (Utterance 20, p. 30, 1. 512)
}

From the excerpt above, it implies that the actor physically does something which is carrying baskets or sacks. Sumarni is the actor in this process. It is a material intention [actor] because there is an action as a result to reach a goal. The entities of the goal are baskets or sacks which are considered as heavy objects. It can be concluded that Sumarni is being able to lift up objects which are not light.

\section{Material Processes Intention [affected]}

From a feminist perspective, the concern of material process intention as if the character is affected extents that the character becomes a victim and mostly passive. In this study, Sumarni's utterances imply that sometimes she becomes a victim because there are characters that make her getting into trouble. It can be seen in the following excerpts:

\section{Excerpt 22}

$$
\begin{array}{|l|l|}
\hline \text { First they took my pans. } & \text { Material process intention [affected] } \\
\hline
\end{array}
$$

(Utterance 60; p. 67, 1. 542)

The context of the utterance above is the heated argument between Sumarni and her husband. Sumarni feels angry because the soldiers like to come for asking security money but they took her trades. The use of the material intention is to express that there are people who took her pans but she cannot do anything. The reason is that the civilians will be jailed if they do not obey the authority.

\section{Material Process Supervention [actor]}

The material process supervention found in Sumarni utterances to note that she sometimes appears as a character who says something out of her intention. There is few number of material process supervention used in her utterances. However, in relation to have best understanding within the purpose of this process, there are some excerpt which can be seen as below:

\section{Excerpt 28}

\begin{tabular}{|l|l|}
\hline Then why do I have to pay the fine? & $\begin{array}{l}\text { Material process supervention } \\
\text { [actor] }\end{array}$ \\
\hline
\end{tabular}

(Utterance 102; p. 111, 1. 557)

The context of the excerpt above is a complaint of Sumarni upon the police officer who charges her because of the accident happened to her car. Based on the 
Ayu Monita Eka Shinta, Feminism Reality as Expressed by Sumarni in the Years of The Voiceless Novel by Okky Madasari: A Critical Discourse Analysis

previous utterance, she states that whether the car which made a cause of injuries then she does need to pay the fine. Sumarni tries to be free from getting the fine from the police officer by saying this utterance. It can be seen from the material process supervention above when she is questioning to the police about the reason of charging her only rather than the driver who made the accident happens.

\section{Material Process Supervention [affected]}

Below are the excerpts of Sumarni selected utterances containing material processes supervention as she is affected because of other characters in the novel. In relation to the matter above, it can be seen that Sumarni has no choice when the money she lends to others cannot be paid back all since her neighbor lend a lot of money. On the other hand, she shows her resignation through supervention when she tells about her husband who has a mistress. It means that actually she does not intend to know about her husband's affair. Then this process reveals that Sumarni also becomes a victim or a passive one because of the action of another.

\section{Excerpt 34}

\begin{tabular}{|l|l|}
\hline $\begin{array}{l}\text { He's out having fun with other } \\
\text { women. }\end{array}$ & $\begin{array}{l}\text { Material process supervention } \\
\text { [affected] }\end{array}$ \\
\hline
\end{tabular}

(Utterance 36, p. 49, 1. 77)

The excerpt above has a context which wants to tell the interlocutor know the madness of Sumarni about Teja. The action made by Teja makes Sumarni gets suffered so it is called material supervention which Sumarni as an affected. The process is attached a circumstance as an accompaniment which tells about with who the action is being done. That is one of the trigger which leads to a conclusion that as a wife, Sumarni becomes a victim in her marriage.

\section{Mental Processes Internalized}

The use of mental process internalized within Sumarni's utterances reveals that she appears as an introspective woman. The findings also shows that mental internalized processes are mostly relating with the affection or feeling rather than cognition. It can be seen from the use of mental as affective within each process. There are selected examples which are given as the excerpts below:

\section{Excerpt 40}

\begin{tabular}{|l|l|}
\hline I don't want to get paid with cassavas anymore. & $\begin{array}{l}\text { Mental process } \\
\text { internalized }\end{array}$ \\
\hline
\end{tabular}

(Utterance 21; p. 30, 1. 517) 
On the excerpt above, Sumarni uses a mental internalized process to state her feeling that she does not want to be paid by cassavas. It implies that she tries to change her living by starting to be paid by money rather than by cassavas.

\section{Mental Processes Externalized}

The mental externalized processes are found in Sumarni's utterances. . The finding shows that mental perceptive processes are used by her. The use of this process is lower than internalized processes. It means that she mostly uses feeling rather than her perceptive to control other character. However, in this process, she does not appear as a Senser itself but as the one who commands other character to respect her and asks for an opinion. It can be seen from the excerpts below:

Excerpt 46

\begin{tabular}{|c|c|}
\hline listen,Yuk! & Mental process externalized \\
\hline
\end{tabular}

(Utterance 7; p. 12, 1. 88)

The context of the excerpt 46 is that when Sumarni asks her daughter to listen her crying about her grandchildren. It means that Sumarni wants to be listened so that is why she commands her daughter to use her mental perceptive which is called as mental externalized in the feminist stylistic.

\section{Feminism Reality realized by Sumarni in The Years of the Voiceless novel}

The relation between elements of feminist stylistic and triangulatory approach is to reveal a feminism reality which reflected by Sumarni in the novel. Sumarni understands in how to maintain her utterances when she speaks to interlocutors who have a lower status, such as servant, driver, daughter, and debtors. However, she appears as voiceless when the authority as hegemony is more powerful than her.

The elements found in the woman's position shows how Sumarni's ability in using the utterances. From the transitivity choices analysis, relational processes are mostly used by Sumarni. The relational processes are helpful to identify something or someone and assign a quality. It can be seen from the use of relational process for identify her job, her quality, her position. As a matter of fact, those relational processes are indeed helping her in emphasize her position while speak to another character. She wants to be recognized by other characters such as her husband, mother, servant, daughter, and the soldiers. The finding shows that Sumarni assigns her status as a mother, a trader, a moneylender, and a sugar-cane field owner. The achievement of Sumarni is considered to see how she is placed since there is a stereotype of Eastern culture that a woman must be becomes a housewife and depended on husband. On the other hand, the use of relational process to show her disagreement such as when her husband asks her to obey the soldiers, but she even 
Ayu Monita Eka Shinta, Feminism Reality as Expressed by Sumarni in the Years of The Voiceless Novel by Okky Madasari: A Critical Discourse Analysis

gives her argument. It shows that she is not voiceless to give her argument toward husband. In addition, she uses relational process to refuse some people who intend lending money.

The result of material process intention shows that Sumarni is an active woman. It can be seen from the mostly number of material intention process through her utterances. People think that women are powerless physically. Here, Sumarni, as woman, shows her power through utterances when she speaks towards interlocutors. On the analysis of material intention, she appears as an actor who takes more action in doing something more often rather than an affected or goal. On the other hand, she intends to make other character respect her from what she does. However, the use of material process intention which places Sumarni as an affected wants to show causes which make her getting suffered. It can be seen from her husband's infidelity.

The other element in transitivity choices which is mental internalized and externalized. It is found that the internalized is higher rather than the externalized process. When she uses mostly of internalized, it means that she appears as an introspective woman instead of careless. In her utterance, the use of mental internalized is still under material process intention. This finding is quite different with the stereotype of previous research found by Mills and Halliday. In this study, Sumarni gives a new perception in how woman maintain their mental process so other will not recognize her as a weak woman.

According to Wodak's approach who is focused on the specific contents, this novel has a nationalist and racist content. This can be seen from a fear which comes to Sumarni and another civilian if they are called as a member of Indonesian Communist Party. It shows the position of civilian including a woman who has a limitation job. They are not allowed to have men's job such as a porter, a leader, a moneylender, and so on and so forth. It relates with the idealism of the government to create an independent economically upon civilians since the setting of time is on Soeharto's regime.

Finally, Sumarni appears as a common woman as the main character in the novel since she is placed as an independent woman. It can be seen from the job of Sumarni. She is a daughter from a woman who works at the market by peeling cassavas. At the end, she becomes a successful sugarcane field owner. It relates with the context of the story which mention about the years of Indonesian Communist party. However, the feminism reality as expressed by Sumarni at this novel suggests how she understands that a woman must be independent and be responsible with her family.

\section{CONCLUSION}

The findings show that Sumarni wants to be recognized among interlocutors, it can be seen from the highest number of relational process as a transitivity choices. The relational processes are used to be a tool for Sumarni to advise her best friend, 
to assign herself to be recognized, and to refuse her neighbor who wants to lend money. While she is an active character can be seen from the higher number of material intention process as an actor rather than an affected. The use of feminist stylistic elements at the level of sentence also gives a perspective about how woman uses her language in maintaining the condition and emotion. While a triangulatory approach helps the researcher in revealing Sumarni's power by correlating with linguistic analysis. As the main idea of this conclusion, Sumarni shows up as a voiceless woman in facing authority but she has power through her utterance when the interlocutors are more powerless or have lower social status than her. It also can be concluded that Sumarni is not a common woman since she is a character who shows her strength to be equal in society especially towards men. However, the author wants to emphasize the idea of feminism reality realized by Sumarni the feminism reality as expressed by Sumarni at this novel a woman must be independent and be responsible upon society and family.

\section{REFERENCES}

Baxter, Judith. (2003). Positioning Gender in Discourse: a feminist methodology. New York: Palgrave Macmillan.

DeFransisco, Victoria. (1997). 'Gender, Power And Practice: Or, Putting Your Money (And Your Research) Where Your Mouth Is', in Sage. 1997, Ruth Wodak (ed.), Gender and Discourse, London: Sage, pp 37-56.

Walter, Elizabeth. (2008). Cambridge Advanced Learner's Dictionary Third Edition. Cambridge: Cambridge University Press.

Coates, Jennifer (ed). (1998). Language and Gender: A Reader. Oxford.

Cresswell, J.W. (1998). Qualitative inquiry and research design: Choosing among five traditions. London: Sage.

Grainger, K. (2010). Review of Gender talk: Feminism, discourse and conversation analysis, Susan Speer. London and New York: Routledge, pp. 237. G\&L vol 3.2 2009, 289-292. doi: 10.1558/genl.v3i2.289.

Halliday, M.A.K. (1994). Introduction to Functional Grammar. London: Edward Arnold.

Hua, Chen. (2013). "Critical Discourse Analysis of Women Language at the Lexical Level in Sense and Sensibility". Part-II: Social Sciences and Humanities, Vol. 4 (No.2 March 2013), 347-361. Retrieved from: www.journals.savap.org.pk 
Ayu Monita Eka Shinta, Feminism Reality as Expressed by Sumarni in the Years of The Voiceless Novel by Okky Madasari: A Critical Discourse Analysis

Johnson, B., \& Christensen, L. (2008).Educational research: Quantitative, qualitative, and mixed approaches (p. 34). Thousand Oaks, CA: Sage Publications.

Lazar, Michelle M. (2005). "Feminist CDA as Political Perspective and Praxis", in Palgrae Macmillan. 2005, M. M. Lazar (ed.), Feminist Critical Discourse Analysis. Gender, Power, and Ideology in Discourse, Basingstoke: Palgrae Macmillan, 1- 28.

Lehtohnen, Sanna. (2007). "Feminist Critical Discourse Analysis and Chidren's Fantasy Fiction - Modelling A New Approach". Presented at "Past, present, future - From women's studies to post-gender research" 14-17 June, 2007, Umeå, Sweden.

Madasari, Okky. (2013). The Years of the Voiceless. Jakarta: Gramedia.

Matthiessen, M.I.M. (2004). An Introduction to Functional Grammar: third edition. New York: Oxford University Press.

Meyer, Charles F. (2009). Introducing English Linguistics. London: Cambridge University Press

Mills, Sara. (1995). Feminist Stylistic. London:

Routledge. Mills, Sara. (1997). Discourse. New York:

Routledge.

Rokhmansyah, Alfian. (2012, November 3). Orde Baru sebagai LandasanFabuladalam Novel Entrok Karya Okky Madasari (Kajian Formalisme Rusia dan Hegemoni). http://www.ziddu.com/download/20864450/ ORDEBARUSEBAGAI LANDASANFABULAArtikel_docx.pdf.html, retrieved on January $5^{\text {th }}, 2015$.

Sodikin, Asep D. (2011). Perlawanan Perempuan Akibat Ketidakadilan Gender dalam Novel Entrok Karya Okky Madasari. http://etd.ugm.ac.id/index.php?mod= opac\&sub=Opac\&act=view \&typ=html\&perpus_id=\&perpus=1\&searchstring= $\%$ 20ketidakadilan\%20gender \&self $=1 \&$ op $=$ review, retrieved on January $5^{\text {th }}$, 2015.

Silva, D.E.G. (2006). Critical Discourse Analysis and the Functional Bases of Language. In Proceedings: $33^{\text {rd }}$ International Systemic Functional Congress (ISFC) 2006. pp 931-949. 
Stephens, John. (2006). Theory and Critical Practice, in Canadian Children's Literature, Vol. 32 No. 1, 132- 144.

Tenorio, E. H. Critical Discourse Analysis, An overview. University of Granada. Vol 10, No 1 (2011).Retrieved from: ojs.ub.gu.se on October 25, 2014.

Udasmoro, W., Ulinnuha, R and Wijaya, Y. (2013). 'Critical Discourse Analysis: Theory and Method in Social and Literary Framework.' In Indonesian Journal of Applied Linguistics, Vol. 2 No. 2, January 2013, pp. 262-274. Retrieved from:

http.ejournal.upi.eduindex.phpIJALarticleview170 on December 16, 2014 at 4:52 PM.

Wodak, Ruth. (2009). 'Critical Discourse Analysis: History, Agenda, Theory, and Methodology' in R. Wodak, \& M. Meyer (Eds.), Methods of Critical Discourse Analysis. (pp. 1-33). London: Sage ( $2^{\text {nd }}$ revised edition).

Wodak, Ruth. (2005). "Gender Mainstreaming and the European Union: Interdisciplinarity, Gender Studies, and CDA" in Palgrave Macmillan. 2005, M. M. Lazar (ed.), Feminist Critical Discourse Analysis. Gender, Power, and Ideology in Discourse, Basingstoke: Palgrae Macmillan, 90-113. 